\title{
The Use of Computer-Based Image Analysis on Colour Determination of Liquid Smoked Trout (Oncorhynchus mykiss) Treated with Different Dry Salt-Sugar Mixtures
}

\author{
Zayde Ayvaz ${ }^{1 *}$, Fikret Çakır ${ }^{1}$, Hatice Gündüz ${ }^{2}$, Mehmet Erdağ ${ }^{1}$ \\ ${ }^{1}$ Faculty of Marine Science and Technology, Çanakkale Onsekiz Mart University, 17100 Çanakkale, Turkey. \\ ${ }^{2}$ Faculty of Fisheries, Izmir Katip Celebi University, 35620 Izmir, Turkey
}

\begin{tabular}{l}
\hline A R T I C L E I N F O \\
Research Article \\
Received 26 July 2017 \\
Accepted 23 October 2017 \\
\hline
\end{tabular}

Keywords:

Computer based image analysis Dry Salting

Shelf life

Smoking

Trout

*Corresponding Author: E-mail: zaydealcicek@gmail.com

\begin{abstract}
A B S T R A C T
In this study, the changes in \% yield, dry matter, ash, lipid, protein content, water activity, $\mathrm{pH}$, total volatile basic nitrogen (TVB-N), total viable aerobic count (TVC), yeast and mold count, lactic acid bacteria (LAB), colour parameters and sensorial properties were analysed in rainbow trout (Oncorhynchus mykiss) exposed to either salt only or two different salt-sugar mixture treatments. For this purpose, three groups were formed. For the first, second and third group, fish samples were treated with only salt (S), salt and sugar blend (WS) and salt and brown sugar blend (BS), respectively. Then, the samples were vacuum packaged and stored at $+4^{\circ} \mathrm{C}$ for 3 months. Overall, salt treatments, liquid smoking and cooking as well as storage generally caused remarkable changes in the parameters of interest. However, except for the sensory analysis, not a remarkable change was seen when the three groups were compared among themselves. The results of experienced panelists suggested that group BS samples had superior appearance, taste, odor and texture and therefore expected to be more preferred by the potential consumers.
\end{abstract}

DOI: https://doi.org/10.24925/turjaf.v5i12.1528-1535.1446

\section{Introduction}

A diverse and healthy diet is essential for good health. Fish and other seafood in general contribute to a good nutritional status since they are known to be a good source of several nutrients, namely, proteins, very longchain omega-3 fatty acids (EPA and DHA), vitamin D, selenium and iodine. Among the seafood, trout is one of the most cultivated fresh water fish species and world total aquaculture rainbow trout (Oncorhynchus mykiss) production was 396120 tons in 2014 (FAO 2016).

Fish and fish products are quite perishable and therefore require preservation from spoilage during their rigor, processing, storage, and transportation until their final consumption. Various food preservation methods including freezing, marinating, salting and smoking have been utilized to improve the quality, safety and shelf-life of these perishable foods. Along with drying, traditional smoking is known as one of the oldest food preservation methods. Each stage of traditional smoking process (salting, dehydration and smoking) contribute to the preservative effect. Salting and dehydration stages reduce the water activity of foods prior to smoking. Additionally, many studies investigating the effect of antioxidant and antimicrobial properties of smoking on fish and fish products have been conducted up to today (Arvanitoyannis and Kotsanopoulos, 2012; Lingbeck et al., 2014) indicating that antioxidants and antimicrobial components occur upon wood pyrolysis helps the fish preservation. In addition to preservative effect, smoking process also gives a unique taste, colour, and flavour to smoked products.

However, wood smoke also contains some undesirable components like polycyclic aromatic hydrocarbons (PAHs). PAHs forms during pyrolysis (between 500$900^{\circ} \mathrm{C}$ ) and they make up the largest class of carcinogenic chemical compounds. Some of PAHs are also thought to have synergistic effect. These compounds can enter the human body through consumption of smoked products and damage DNA (Šimko, 2002). The indicator compound for PAHs is $\operatorname{Benzo}(a)$ pyrene $(\mathrm{B}(a) \mathrm{P})$. The European Union (EU) has set a limit to $\mathrm{B}(a) \mathrm{P}$ as 0.002 ppm ((EC) No. 835/2011) (Lingbeck et al., 2014).

As an alternative to traditional smoking treatment, the use of liquid smoke condensates have been becoming increasingly popular. According to Varlet et al. (2010), between $20 \%$ and $30 \%$ of European smoked food is treated by liquid smokes. Liquid smoke seafood does not 
contain $\mathrm{B}(a) \mathrm{P}$ in quantifiable levels and usually include it only in trace amounts (Alçiçek et al., 2010; Alcicek, 2011). The liquid smoke application has some other additional advantages over traditional smoking as well. Liquid smoking is easier to apply, requires less time and labour, as well as being environmentally friendly, reusable, and more economical. Additionally, liquid smoke condensates are categorized as all natural antimicrobial in food preservation (Lingbeck et al., 2014). One of the most important challenge associated with the use of liquid smoke flavour on foods is to convince the target consumers that liquid smoke foods has similar color and flavour profile to those of traditionally smoked ones. Therefore, more research focusing on these issue should be conducted for clarification.

Characteristic colour of smoked products (brown/yellow) is mainly originating from phenolic compounds of wood smoke (Varlet et al., 2010). Uneven and non-homogenized colour is the main problem with seafood. Furthermore, if there is a high-fat ratio in fillets, the uneven colour distribution increases after smoking (Espe et al., 2002). Therefore, it is not possible to determine the true colour of seafood by using conventional instrumental colour analysis methods (Kong, et al., 2015b; Yagiz et al., 2009). Computer-based image analysis (CBI) could be an alternative at this point. CBI is used as a novel colour and shape determination techniques for foods. The rationale behind the CBI is to demonstrate the colour features of every single pixel of the food by using special picture taking techniques and processing it with a special software.

Salt is known as the most consumed food additive. Salting or brining is one of the major steps of food smoking and it can be applied as either dry or wet. Martinez et al. (2011) reported that dry salting was the best method to choose for liquid smoking of salmon samples. However, there is no standardized salting method at the moment and, various applications and concentrations are used based on the consumer demand, salt intake regulation of the country, the type of food and such. Salting does not only considerably extend the shelf life of the smoked foodstuff by inactivating the microorganisms and providing longer shelf-life via reducing the water content of cells, it also gives desirable texture, taste and spectacular palatability due to the flavour produced by the smoke. $\mathrm{Cl}$ ions have toxic effect for many microorganisms (Leroi and Joffraud, 2000). The salt content of smoked product must not be under $3 \%$ due to microbiological safety issues (Anonymous, 2000). However, high salt content in the smoked product is known to reduce the consumer acceptability and it is harmful for the human cardiovascular system (Alçiçek et al., 2010). As an alternative approach, salt level added can be reduced by using sugar-salt mixtures. Sugar molecules are bigger than salt molecules which cause more water reduction while less salt intake in tissue. Therefore, a product with less salt, slight taste of sugar and improved texture can be obtained by using sugar-salt mixtures (Kong et al., 2015; Ayvaz et al., 2017). The use of brown sugar and salt mixtures are especially more common in the case of cold smoked salmon. The flesh acquires soft and jelly texture, as well as desirable redness through the salt/brown sugar mixture. The main difference between brown sugar and white sugar is the presence of components called 'molasses' in brown sugar. However, there is no scientific evidence showing any difference between the use of white or brown sugar and their corresponding effects on smoked seafood. In several studies in the literature regarding the effects of sugar and salt on the seafood (Martinez et al., 2011, 2012; Hong et al., 2012; Kong et al., 2015; Ayvaz et al., 2017) have been investigated. However, differences in visual attributes of salt or sugar applied products have not been determined by using computer-based image analysis, yet.

Therefore, the aims of this study included to determine the effect of $\mathrm{NaCl}$ and/or sugar mixtures salting techniques on the shelf-life of liquid smoked rainbow trout fillets. The physico-chemical, microbial and sensorial properties were determined during shelf-life and the results were compared among the groups of S, WS and BS.

\section{Materials and Methods}

\section{Raw Material}

After harvesting, 160 individual Rainbow trout (Oncorhynchus mykiss) (150 $\pm 20 \mathrm{~g})$ were immediately transferred to our laboratory in sealed polystyrene foam boxes filled with ice. Prior to processing, the fish samples were eviscerated by hand, de-headed and washed with tap water. In addition to raw samples, three other groups were created as follows:

$\begin{array}{ll}\text { Group S } & \text { :Only dry salt }(\mathrm{NaCl}) \text { applied group. } \\ \text { Group WS } & \begin{array}{l}: 50 \% \text { dry salt }(\mathrm{NaCl}) \text { and } 50 \% \text { white } \\ \text { sugar applied group. }\end{array} \\ \text { Group BS } & \begin{array}{l}: 50 \% \text { dry salt }(\mathrm{NaCl}) \text { and } 50 \% \text { brown } \\ \text { sugar applied group. }\end{array}\end{array}$

\section{Salting}

Once grouping is completed, the mixtures required for each group were prepared based on the proportions aforementioned. The mixture of choice was placed on the bottom of a polystyrene foam box and the trout fillets were laid on the mixture as another layer. Lastly, one more layer of the mixture used on the bottom was placed on top of the fillets. Total weight of the mixtures and fish fillets used were set to the same weight. Samples were then stored at $+4^{\circ} \mathrm{C}$ for $24 \mathrm{~h}$.

Liquid Smoke Condensate Application and Cooking (ASC) Liquid smoke condensate (Red Arrow, SmokEz-C-10, mesquite, water based) was purchased from a food additive company (GMT Food Ingredients Co. Istanbul, Turkey). After brining, the fillets were washed with tap water and dried using a paper towel. Then, the samples were dipped in liquid smoke condensate for 3 minutes. After dipping, the fillets laid on a grid for percolation.

Due to more homogenize hot air circulation, a turbo fan oven (ZPE 4E Multifunction Oven, Turkey) was used for cooking. The oven temperature was set to $120^{\circ} \mathrm{C}$. The fillets were cooked until their inside temperature reached to $80^{\circ} \mathrm{C}$ (hot smoking conditions). Then, the samples were removed from the oven and cooled at room temperature for 20 minutes prior to packaging. 


\section{Packaging and Storage}

Samples were vacuum packaged $(50 \mu \mathrm{m}$ and 160 $\left.\mathrm{cm} 3 / \mathrm{m} 2 / 24 \mathrm{~h} \mathrm{O}_{2}\right)$ using a Multivac Vacuum Sealer $(\mathrm{C} 100-$ Sepp Haggenmüller $\mathrm{GmbH} \&$ Co. KG, Wolfertschwenden, Germany) and stored at $+4^{\circ} \mathrm{C}$ (EKT 725 Emsaş Cooling Systems, Turkey) until the following analyses.

\section{Physiochemical Analysis}

Prior to physicochemical analyses, edible parts of the fish samples were homogenized using a kitchen blender. Physicochemical analyses of the samples were conducted at different intervals; raw fillets, after salting, after liquid smoking and subsequent cooking as well as after 3 months of storage at $4^{\circ} \mathrm{C}$.

The average weight of the samples from whole fish up to final cooking was measured corresponding \% yield values were also calculated in this study. Chemical composition of the fish samples was measured following standard methods, and protocols Turkish Food Composition Database (TurKomp) (SOP 001.01 for dry matter, SOP 003.01 for ash, SOP 002.01 for protein) (2014). Dry matter content was analysed by oven drying of $3 \mathrm{~g}$ of liquid-smoked rainbow trout at $105^{\circ} \mathrm{C}$ until a constant weight was achieved. For ash determination, fish samples were weighed and placed in a muffle furnace at $550 \pm 25^{\circ} \mathrm{C}$. Percent protein (Kjeldahl $\mathrm{N} \times 6.25$ ) was determined using $1 \mathrm{~g}$ sample for each treatment. Total lipid content was analysed by Bligh and Dyer extraction method (Bligh and Dyer 1959). For pH measurement, 10g sample was mixed with $100 \mathrm{~mL}$ of distilled water and the $\mathrm{pH}$ was measured using a $\mathrm{pH}$ meter (Hanna/ HI 8314, USA). The water activity $\left(a_{\mathrm{w}}\right)$ of the samples was measured using an Aqua Lab Series/ 4 TE (USA). The samples were skinned and minced finely before they were placed in the chamber of the device. Values of $a_{\mathrm{w}}$ were read after moisture equilibration at $25^{\circ} \mathrm{C}(\sim 20 \mathrm{~min})$. TVB-N analysis was performed using the methods of Goulas and Kontominas (2005). All analyses were carried out in triplicate.

\section{Microbiological Analysis}

Total viable counts (TVCs), lactic acid bacteria (LAB), yeast and mold counts of the trout samples as raw, salted, liquid smoked and cooked as well as after 3 month storage were determined. Ten grams of each sample homogenate were diluted to $90 \mathrm{~mL}$ with peptone water (1\%) buffered at $\mathrm{pH} 7.5$. Rainbow trout samples were homogenized in Tryptone water for $30 \mathrm{~s}$ in a stomacher. Serial dilutions were prepared until $10^{-7} \mathrm{~g} / \mathrm{ml}$ samples were obtained. One millilitre of each dilution was placed in a petri dish and $15 \mathrm{~mL}$ of plate count agar were added for TVC. TVC counts were performed on pour plates with plate-count agar (PCA Merck KGaA, Darmstadt, Germany), after $48 \mathrm{~h}$ at $37^{\circ} \mathrm{C}$. De Man Rogosa Sharpe (MRS Merck KGaA, Darmstadt, Germany) (15 mL) agar was used for LAB. Petri dishes were inverted and placed in an incubator at $30^{\circ} \mathrm{C}$ for $48 \mathrm{~h}$ (Baumgartner et al. 1986). After incubation, TVC, and LAB were counted, following the rules recommended by Gilliland, Busta, Brinda, and Campbell (1976). Yeast and mold counts were determined by the surface spread plate method on Dichloran Rose Bengal Chloramphenicol (DRBC) agar
(King et al. 1979). DRBC agar plates were incubated upright at $25^{\circ} \mathrm{C}$ for 5 days. The minimum level of detection was $10 \mathrm{cfu} / \mathrm{ml}$.

\section{Computer Based Image Analysis}

The illumination system (light box) and the LensEye software (Gainesville, FL, USA) were developed in our lab to capture the images and analyze the visual attributes of the samples. The illumination system $(122 \mathrm{~cm}$ high, $61 \mathrm{~cm}$ wide, $46 \mathrm{~cm}$ deep) had 2 LED panel system (color temperature $=6500 \mathrm{~K}$ ) emulating the $\mathrm{D}_{65}$ illumination (natural daylight at noon). There was one light at the top, used for front lighting, and other at the bottom, used for bottom lighting. The surface of the upper light box facing the sample space was covered with a polarizing sheet (Rosco, Stamford, CT, USA).

Front-lighted and back-lighted images were acquired using a Nikon D300 digital camera (Nikon Corp., Tokyo, Japan). The camera settings for the front-lighting conditions were: exposure mode, manual; shutter speed, $1.6 \mathrm{~s}$; aperture, f/6.3; ISO sensitivity, 200; white balance, preset manual. Camera settings for the back-lighting conditions were: shutter speed, $0.25 \mathrm{~s}$; aperture, f/11. The camera had an 18-200 mm zoom Nikkor lens with a 72 $\mathrm{mm}$ diameter circular polarizing filter attached. A color standard (Gretag Color Checker, X-Rite Inc., Grand Rapids, MI, USA) and a square black plate $\left(16 \mathrm{~cm}^{2}\right)$ were placed alongside the sample during the picture acquisition. The color standard was used for color calibration purposes. The pictures acquired were resized, cleaned and converted to bmp files using Adobe Photoshop 13.0.1.3 CS 6 (Adobe Systems Inc, California, U.S.A.) before they were analyzed using LensEye Version 11.4.1 software (ECS, Gainesville, FL, USA). LensEye provided the average $L^{*}, a^{*}$ and $b^{*}$ values of the samples (Yagiz et al., 2009).

\section{Sensory Analysis}

Five experienced panelists, who were trained in sensory descriptors for liquid smoked trout, were participated to evaluate the quality of rainbow trout fillets after cooking and 3 month storage. Rainbow trout fillets were assessed on the basis of color, appearance, taste, odor and texture characteristics using Torry Score described at Hyldig (2010).

\section{Statistical Analysis}

Statistical analysis was performed using SPSS for Windows Version 16 (SPSS Inc., Chicago, IL, USA). For analysis of variance (ANOVA), Tukey's honest significant difference (HSD) test was used to compare the averages $(\mathrm{P}<0.05)$.

\section{Results and Discussion:}

\section{Proximate Analysis Results}

Weight loss and resulting yield (\%) values for the three groups created (S, BS and WS) are shown in Table 1. About $40 \%$ lost in weight was seen in the fish samples due to evisceration and deheading. When salted, all three groups had nearly $10 \%$ additional loss in yield. Using salt only or salt-sugar mixture did not make any noteworthy difference in $\%$ yield. Upon liquid smoke application and 
further cooking, yield value dropped to lower values with $44.0 \%$ for group $\mathrm{S}$ and 42.0 and $41.1 \%$ for group BS and WS, respectively.

Results of proximate analyses of the samples for raw and processed rainbow trout including dry matter, ash, lipid and protein are given in Table 2. In the literature, numerous studies related to fresh rainbow trout are present; however, most of these studies evaluated only the initial proximate analyses results. However, we also investigated the results after salting, liquid smoking and subsequent cooking applications. For all four parameters, salting treatments caused a significant increase $(\mathrm{P}<0.05)$ for each group compared to raw data. This could be explained by reduced water content of the tissue as a result of salt and sugar addition. Only exception was WS group where no statistical change was observed between raw and liquid smoked and cooked samples. Overall, our results were in accordance with the previous studies (Kolsarici and Özkaya, 1998; Alçiçek, 2011; Gürlekoğlu, 2011).

Raw trout samples had $22.87 \%$ dry matter. Dry matter content of the raw fish significantly increased $(\mathrm{P}<0.05)$ for all three salting types (S, BS and WS) upon both salting and liquid smoking and following cooking treatments (Table 2). The highest dry matter was seen in group $\mathrm{S}(37.82 \%)$ and it was found to be significantly higher than that of BS (29.17\%) and WS (30.06\%). When salting and liquid smoking and cooking were compared for each salting type, only group $S$ had similar results while significantly higher dry matter contents $(\mathrm{P}<0.05)$ were found after liquid smoking compared to after cooking and cooking for groups of BS and WS. However, among the liquid smoked and cooked states of the samples among the groups, no statistical difference $(\mathrm{P}>0.05)$ was found in dry matter contents.

As for the ash, significant increases $(\mathrm{P}<0.05)$ were observed for all groups compared to that of raw sample. This was in agreement with the Esaiassen et al. (2005), who mentioned that salt and glucose addition could increase the mineral composition of the flesh. A similar trend to dry matter results was also seen for ash content. The highest ash content was seen for the group $\mathrm{S}$ after salting $(8.66 \%)$ and this value significantly decreased $(\mathrm{P}<0.05)$ when liquid smoking and cooking were applied $(5.71 \%)$. However, in other two groups (BS and WS), ash contents significantly $(\mathrm{P}<0.05)$ increased after liquid smoke and cooking treatments. However, among the liquid smoked and cooked samples of the three groups, no statistical difference $(\mathrm{P}>0.05)$ was found in ash contents.

Average percent lipid level of the raw sample was $4.54(\%)$. Except after liquid smoking and cooking applied samples of group WS, lipid percent levels significantly $(\mathrm{P}<0.05)$ increased for all groups. After salting, groups $\mathrm{S}$ and WS gave the highest lipid levels (9.60 and $9.87 \%$, respectively) while the total lipid level of group BS was significantly lower after salting (6.49\%). Within the same salting groups, \% lipid level significantly decreased for group $\mathrm{S}$ whereas no significant difference was observed between salted and liquid smoked and cooked samples for group BS and WS. When final products compared, group BS samples had significantly $(\mathrm{P}<0.05)$ higher lipid levels $(7.39 \%)$ than those of group $\mathrm{S}$ $(6.08 \%)$ and WS $(5.63 \%)$.

Table 1 Weight loss and corresponding yield values as affected by the treatments

\begin{tabular}{l|cccccc}
\hline \multirow{2}{*}{ Treatment } & \multicolumn{2}{|c}{$\mathrm{S}$} & \multicolumn{2}{c}{$\mathrm{BS}$} & \multicolumn{2}{c}{$\mathrm{WS}$} \\
\cline { 2 - 7 } & $\mathrm{W}(\mathrm{g})$ & $\mathrm{Y}(\%)$ & $\mathrm{W}(\mathrm{g})$ & $\mathrm{Y}(\%)$ & $\mathrm{W}(\mathrm{g})$ & $\mathrm{Y}(\%)$ \\
\hline Whole & $306.8 \pm 53.8$ & - & $311.0 \pm 35.4$ & - & $311.9 \pm 55.3$ & - \\
Eviscerated and deheaded & $195.9 \pm 37.1$ & 63.9 & $189.2 \pm 25.9$ & 60.8 & $190.9 \pm 32.7$ & 61.2 \\
After salting & $163.6 \pm 31.2$ & 53.3 & $164.1 \pm 19.6$ & 52.8 & $166.8 \pm 30.8$ & 53.5 \\
Liquid smoked and cooked & $135.1 \pm 27.2$ & 44.0 & $130.7 \pm 17.5$ & 42.0 & $128.1 \pm 23.7$ & 41.1 \\
\hline
\end{tabular}

W: Weight (g) Average \pm SD, Y: Yield (\%), SD: Standard deviation, Results are shown as mean value \pm standard deviation, S stands for the group salted using dry salt only, BS stands for the group salted using dry salt and brown sugar mixture (50-50\%), WS stands for the group salted using dry salt and white sugar mixture (50-50\%)

Table 2 Composition of the trout samples as affected by the treatments

\begin{tabular}{|c|c|c|c|c|c|}
\hline Groups & Treatments & Dry Matter (\%) & $\operatorname{Ash}(\%)$ & Lipid (\%) & Protein $(\%)$ \\
\hline Control & Raw & $22.87 \pm 0.65^{\mathrm{a}}$ & $1.35 \pm 0.02^{\mathrm{a}}$ & $4.54 \pm 0.16^{\mathrm{a}}$ & $18.96 \pm 0.34^{\mathrm{a}}$ \\
\hline \multirow{2}{*}{ S } & After salting & $37.82 \pm 2.27^{1 \mathrm{~A}}$ & $8.66 \pm 0.49^{1 \mathrm{~A}}$ & $9.60 \pm 1.87^{1 \mathrm{~A}}$ & $24.55 \pm 0.38^{1 \mathrm{~A}}$ \\
\hline & After LS and cooking & $36.18 \pm 0.13^{1 \mathrm{~A}}$ & $5.71 \pm 1.5^{2 \mathrm{~A}}$ & $6.08 \pm 0.31^{2 \mathrm{~A}}$ & $27.65 \pm 0.17^{2 \mathrm{~A}}$ \\
\hline \multirow{2}{*}{$\mathrm{BS}$} & After salting & $29.17 \pm 0.80^{1 \mathrm{~B}}$ & $3.04 \pm 0.28^{1 \mathrm{~B}}$ & $6.49 \pm 0.15^{1 \mathrm{~B}}$ & $22.86 \pm 0.56^{1 \mathrm{~B}}$ \\
\hline & After LS and cooking & $35.64 \pm 0.70^{2 \mathrm{~A}}$ & $4.16 \pm 0.03^{2 \mathrm{~A}}$ & $7.39 \pm 0.14^{2 \mathrm{~B}}$ & $30.45 \pm 0.47^{2 \mathrm{~B}}$ \\
\hline \multirow{2}{*}{ WS } & After salting & $30.06 \pm 1.04^{1 \mathrm{~B}}$ & $3.90 \pm 0.171 \mathrm{~B}$ & $9.87 \pm 0.76^{1 \mathrm{~A}}$ & $20.7 \pm 0.62^{1 C}$ \\
\hline & After LS and cooking & $36.81 \pm 0.84^{2 \mathrm{~A}}$ & $5.04 \pm 0.20^{2 \mathrm{~A}}$ & $5.63 \pm 0.45^{\mathrm{a} 2 \mathrm{~A}}$ & $29.53 \pm 0.50^{2 \mathrm{~B}}$ \\
\hline
\end{tabular}

Results are shown as mean value \pm standard deviation, $\mathrm{S}$ stands for the group salted using dry salt only, BS stands for the group salted using dry salt and brown sugar mixture (50-50\%), WS stands for the group salted using dry salt and white sugar mixture (50-50\%), LS stands for liquid smoke application, Different lowercase letters represent significant difference $(\mathrm{P}<0.05)$ between the result of raw sample and treated samples $($ when there was a significant difference, no lowercase letter was added), Different uppercase letters represent significant differences $(\mathrm{P}<0.05)$ between salting of three groups (S, BS and WS) or between after LS and cooking of the three groups (S, BS and WS), Different numbers represent significant difference $(\mathrm{P}<0.05)$ between salting and after LS and cooking within each group. 
Table 3 Water activity, $\mathrm{pH}$ and TVB-N values of the trout samples as affected by the treatments



T: Treatment, R: Raw, AST: After Salting, LSC: LS and Cooking, AS: After storage, Results are shown as mean value \pm standard deviation, S stands for the group salted using dry salt only, BS stands for the group salted using dry salt and brown sugar mixture (50-50\%), WS stands for the group salted using dry salt and white sugar mixture (50-50\%), LS stands for liquid smoke application, Different lowercase letters represent significant difference $(\mathrm{P}<0.05)$ among the result of different groups, Different uppercase letters represent significant differences $(\mathrm{P}<0.05)$ within a column of the same group.

Table 4 Microbiological results of the trout samples as affected by the treatments

\begin{tabular}{|c|c|c|c|c|c|c|c|c|c|}
\hline \multirow{2}{*}{$\mathrm{T}$} & \multicolumn{3}{|c|}{ TVC } & \multicolumn{3}{|c|}{ Yeast and mold } & \multicolumn{3}{|c|}{ LAB } \\
\hline & $\mathrm{S}$ & WS & $\mathrm{BS}$ & $S$ & WS & $\mathrm{BS}$ & $\mathrm{S}$ & WS & $\mathrm{BS}$ \\
\hline$\overline{\mathrm{AST}}$ & $<1^{\mathrm{aB}}$ & $0.31 \pm 0.22^{\mathrm{bB}}$ & $<1^{\mathrm{aB}}$ & $<1^{\mathrm{aB}}$ & $<1^{\mathrm{aB}}$ & $<1^{\mathrm{aB}}$ & $<1^{\mathrm{aB}}$ & $<1^{\mathrm{aB}}$ & $<1^{\mathrm{aB}}$ \\
\hline LSC & $2.35 \pm 0.08^{\mathrm{aC}}$ & $2.53 \pm 0.00^{\mathrm{bC}}$ & $2.20 \pm 0.04^{\mathrm{cC}}$ & $1.49 \pm 0.24^{\mathrm{aC}}$ & $2.40 \pm 0.02^{\mathrm{bC}}$ & $1.70 \pm 0.32^{\mathrm{aC}}$ & $1.76 \pm 0.02^{\mathrm{aC}}$ & $0.38 \pm 0.09^{\mathrm{bC}}$ & $0.52 \pm 0.05^{\mathrm{cA}}$ \\
\hline AS & $2.48 \pm 0.00^{\mathrm{aC}}$ & $2.50 \pm 0.01^{\mathrm{bC}}$ & $2.48 \pm 0.00^{\mathrm{aD}}$ & $2.49 \pm 0.01^{\mathrm{aD}}$ & $2.50 \pm 0.02^{\mathrm{bC}}$ & $2.48 \pm 0.00^{\mathrm{aD}}$ & $2.48 \pm 0.00^{\mathrm{aD}}$ & $2.48 \pm 0.01^{\mathrm{bD}}$ & $2.48 \pm 0.00^{\mathrm{aC}}$ \\
\hline
\end{tabular}

T: Treatment, AST: After Salting LSC: LS and Cooking, AS: After storage, Results are shown as mean value \pm standard deviation log cfu/g, S stands for the group salted using dry salt only, BS stands for the group salted using dry salt and brown sugar mixture (50-50\%), WS stands for the group salted using dry salt and white sugar mixture (50-50\%), LS stands for liquid smoke application, Different lowercase letters represent significant difference $(\mathrm{P}<0.05)$ among the result of different groups, Different uppercase letters represent significant differences $(\mathrm{P}<0.05)$ within a column of the same group

Table 5 Computer-based imaging results of the trout samples as affected by the treatments

\begin{tabular}{|c|c|c|c|c|c|c|c|c|c|}
\hline \multirow{2}{*}{$\mathrm{T}$} & \multicolumn{3}{|c|}{$L^{*}$} & \multicolumn{3}{|c|}{$a^{*}$} & \multicolumn{3}{|c|}{$b^{*}$} \\
\hline & $\mathrm{S}$ & WS & BS & $\mathrm{S}$ & WS & BS & $\mathrm{S}$ & WS & BS \\
\hline $\bar{R}$ & $66.73 \pm 1.70^{\mathrm{bA}}$ & $66.38 \pm 1.77^{\mathrm{abA}}$ & $67.88 \pm 2.15^{\mathrm{aA}}$ & $32.23 \pm 1.54^{\mathrm{abA}}$ & $31.72 \pm 1.57^{\mathrm{aA}}$ & $28.24 \pm 3.30^{\mathrm{bA}}$ & $28.89 \pm 2.46^{\mathrm{aA}}$ & $32.89 \pm 4.14^{\mathrm{aA}}$ & $31.83 \pm 12.00^{\mathrm{a} A}$ \\
\hline AST & $62.31 \pm 1.87^{\mathrm{abB}}$ & $61.73 \pm 1.82^{\mathrm{aB}}$ & $62.71 \pm 2.63^{\mathrm{bB}}$ & $30.36 \pm 1.41^{\mathrm{aB}}$ & $30.01 \pm 1.42^{\mathrm{aB}}$ & $27.14 \pm 2.27^{\mathrm{bB}}$ & $27.36 \pm 3.31^{\mathrm{aB}}$ & $30.43 \pm 1.28^{\mathrm{aA}}$ & $29.49 \pm 4.00^{\mathrm{aA}}$ \\
\hline LSC & $23.63 \pm 2.27^{\mathrm{aC}}$ & $38.60 \pm 3.62^{\mathrm{bC}}$ & $25.69 \pm 3.68^{\mathrm{aC}}$ & $40.43 \pm 1.37^{\mathrm{aC}}$ & $38.42 \pm 1.54^{\mathrm{bC}}$ & $37.73 \pm 2.04^{\mathrm{cC}}$ & $26.68 \pm 2.57^{\mathrm{aB}}$ & $42.10 \pm 1.82^{\mathrm{bB}}$ & $29.71 \pm 4.32^{\mathrm{cA}}$ \\
\hline AS & $38.39 \pm 2.50^{\mathrm{aD}}$ & $30.71 \pm 0.99^{\mathrm{bD}}$ & $26.82 \pm 3.70^{\mathrm{aC}}$ & $35.36 \pm 0.57^{\mathrm{aD}}$ & $35.93 \pm 0.53^{\mathrm{aD}}$ & $28.13 \pm 0.87^{\mathrm{bAI}}$ & ${ }^{\mathrm{D}} 36.27 \pm 1.67^{\mathrm{aC}}$ & $35.68 \pm 2.65^{\mathrm{bACD}}$ & $26.66 \pm 5.02^{\mathrm{aB}}$ \\
\hline
\end{tabular}

T: Treatment, R: Raw, AST: After Salting LSC: LS and Cooking, AS: After storage, Results are shown as mean value \pm standard deviation, S stands for the group salted using dry salt only, BS stands for the group salted using dry salt and brown sugar mixture (50-50\%), WS stands for the group salted using dry salt and white sugar mixture (50-50\%), LS stands for liquid smoke application, Different lowercase letters represent significant difference $(\mathrm{P}<0.05)$ among the result of different groups, Different uppercase letters represent significant differences $(\mathrm{P}<0.05)$ within a column of the same group

Table 6 Sensory analysis results of the trout samples as affected by the treatments

\begin{tabular}{|c|c|c|c|c|c|c|c|c|c|}
\hline \multirow{2}{*}{$\mathrm{T}$} & \multicolumn{3}{|c|}{ Color } & \multicolumn{3}{|c|}{ Appearance } & \multicolumn{3}{|c|}{ Taste } \\
\hline & $\mathrm{S}$ & WS & $\mathrm{BS}$ & $\mathrm{S}$ & WS & $\mathrm{BS}$ & $S$ & WS & $\mathrm{BS}$ \\
\hline LSC & $4.67 \pm 0.49^{\mathrm{aA}}$ & $4.47 \pm 0.52^{\mathrm{aA}}$ & $4.67 \pm 0.49^{\mathrm{aA}}$ & $4.13 \pm 0.64^{\mathrm{aA}}$ & $4.53 \pm 0.52^{\mathrm{bA}}$ & $4.40 \pm 0.63^{\mathrm{bA}}$ & $4.13 \pm 0.64^{\mathrm{aA}}$ & $4.47 \pm 0.52^{\mathrm{bA}}$ & $4.47 \pm 0.52^{\mathrm{bA}}$ \\
\hline $\mathrm{AS}$ & $2.67 \pm 0.49^{\mathrm{aD}}$ & $2.53 \pm 0.52^{\mathrm{bC}}$ & $2.80 \pm 0.41^{\mathrm{aD}}$ & $2.73 \pm 0.46^{\mathrm{aC}}$ & $2.80 \pm 0.41^{\mathrm{aC}}$ & $2.73 \pm 0.46^{\mathrm{bB}}$ & $2.60 \pm 0.51^{\mathrm{aB}}$ & $2.67 \pm 0.49^{\mathrm{aC}}$ & $2.27 \pm 0.46^{\mathrm{bB}}$ \\
\hline \multirow{2}{*}{$\mathrm{T}$} & \multicolumn{3}{|c|}{ Odor } & \multicolumn{3}{|c|}{ Texture } & & & \\
\hline & $S$ & WS & BS & $S$ & WS & BS & & & \\
\hline LSC & $4.33 \pm 0.49^{\mathrm{aA}}$ & $4.33 \pm 0.72^{\mathrm{aA}}$ & $4.40 \pm 0.63^{\mathrm{aA}}$ & $4.53 \pm 0.52^{\mathrm{aA}}$ & $4.47 \pm 0.52^{\mathrm{aA}}$ & $4.47 \pm 0.52^{\mathrm{aA}}$ & & & \\
\hline $\mathrm{AS}$ & $2.07 \pm 0.26^{\mathrm{aD}}$ & $2.93 \pm 0.26^{\mathrm{bB}}$ & $2.53 \pm 0.52^{\mathrm{bB}}$ & $2.27 \pm 0.46^{\mathrm{aD}}$ & $2.60 \pm 0.51^{\mathrm{bC}}$ & $2.27 \pm 0.46^{\mathrm{aB}}$ & & & \\
\hline
\end{tabular}

T: Treatment, LSC: LS and Cooking, AS: After storage, Results are shown as mean value \pm standard deviation, $\mathrm{S}$ stands for the group salted using dry salt only, BS stands for the group salted using dry salt and brown sugar mixture (50-50\%), WS stands for the group salted using dry salt and white sugar mixture (50-50\%), LS stands for liquid smoke application, Different lowercase letters represent significant difference $(\mathrm{P}<0.05)$ among the result of different groups, Different uppercase letters represent significant differences $(\mathrm{P}<0.05)$ within a column of the same group

Average protein content of the raw samples was determined as $18.96 \%$. This value significantly increased for all salting applications, with group S, BS and WS having 24.55, 22.86 and 20.7\%, respectively. Liquid smoking and cooking treatments remarkably increased $(\mathrm{P}<0.05)$ the protein content in all three groups compared to after salting. Group BS and WS gave higher protein levels than that of group $\mathrm{S}$ in liquid smoked and cooked state.

Water activity and $\mathrm{pH}$ levels of the samples are shown in Table 3. Aw level of raw trout sample was approximately $0.94 \pm 0.01$. As expected, salting applications significantly reduced the water activity of the samples $(0.88 \pm 0.01)$ due to water binding properties of salt and sugars. The lowest water activity values were found in group S, followed by BS and WS. This indicates that the salt reduces water activity further when used alone. However, water activity reducing ability slightly decreased when the salt was mixed with sugar. The differences between groups were not statistically significant $(\mathrm{P}>0.05)$. Interestingly, the water activity of group samples increased immediately after liquid smoking and cooking. This can be explained by the use of a water-based liquid smoke condensate. Although some 
statistical differences were seen among the $a_{w}$ of the groups after 3 month storage, there was no practical difference among the groups. The results show that liquid smoke application increased the water activity of all salted groups. Similar results were also observed in other studies (Kong et al., 2015; Ayvaz et al., 2017).

The specified $\mathrm{pH}$ value for fresh fish is between 6.06.5 and consumable limit is 6.8-7.0. No groups exceeded the consumption limit during our study. The initial $\mathrm{pH}$ of raw rainbow trout was between 6.26 and 6.41. Similar findings were reported by other researchers (Alcicek and Atar, 2010; Alçiçek, 2011). After salting, the pH values were 5.91, 5.94 and 6.18, for S, WS and BS, respectively. As expected, significant statistical differences were found between all groups after salting $(\mathrm{P}<0.05)$. Sahoo et al. (2004) also reported that salting process decreased the $\mathrm{pH}$ values of samples. The results showed that the only salt usage had more significant effect on $\mathrm{pH}$ than using sugar mixes. pH levels of all three group samples got lower after storage with group WS having higher $\mathrm{pH}$ level (5.52) then the other groups (5.38 for group $\mathrm{S}$ and 5.34 for group BS).

\section{TVB-N Results}

TVB-N values of the fresh trout samples were found to be around $17 \mathrm{mg} / 100 \mathrm{~g}$ TVB-N following the harvesting, indicating that the initial TVB-N values of the fillets were in appropriate levels. In this study, the upper limit for TVB-N were set as $25-30 \mathrm{mg} / 100 \mathrm{~g}$. TVB-N levels known to increase continuously due to autolytic degradation of nucleotides and free amino acids during storage (Oehlenschlager 2014). The results showed that TVB-N values of all groups continuously increased through salting, liquid smoking and cooking treatments with group $\mathrm{S}$ and BS having higher TVB-N values (about $20 \mathrm{mg} / 100 \mathrm{~g}$ ). During the 3 month storage, a sharper increase was observed in all three groups, with results being approximately doubled after storage compared to raw samples reaching to $25-30 \mathrm{mg} / 100 \mathrm{~g}$ levels. The results showed that the addition of liquid smoke condensate did not prevent the increase of volatile bases.

\section{Microbiological Analysis Results}

Table 4 shows the changes in TVC, LAB, yeast and mold counts during processes and storage. Various levels of microbiological loads were detected in raw samples of the 3 groups. The initial TVC counts of raw rainbow trout were $1.28,2.43$, and $1.42 \log \mathrm{cfu} / \mathrm{g}$, for $\mathrm{S}$, WS and BS, respectively. After salting, TVC level was reduced to uncountable levels except for the group WS, where there was still $0.31 \log \mathrm{cfu} / \mathrm{g}$. Significant increase was found for TVC count after liquid smoking and cooking treatment despite antimicrobial effect of liquid smoke condensates and heat treatment by cooking. This could be due to the re-contamination during the cooling of the cooked samples in the air. During storage, only group BS samples had significantly higher $(\mathrm{p}<0.05)$ TVC count compared to liquid smoke and cooked samples while other two groups had similar TVC count.

The initial yeast and mold counts of raw rainbow trout were $0.38,1.51$ and $1.04 \log \mathrm{cfu} / \mathrm{g}$, for $\mathrm{S}$, WS and BS, respectively. Salt treatment reduced the level of yeast and mold to uncountable levels in all groups Similar to TVC, after LS+cooking, higher yeast and mold count was seen. The values were further increased significantly $(\mathrm{P}<0.05)$ during the storage for group $\mathrm{S}$ and BS.

The initial LAB count of the raw samples were 0.20, 0.77 and $0.36 \log \mathrm{cfu} / \mathrm{g}$, for $\mathrm{S}$, WS and BS, respectively. Similar to TVC and yeast and mold results, salt treatment reduced the $\mathrm{LAB}$ count to uncountable levels. Cooling process after liquid smoke and cooking and storage in vacuum package allowed LAB contamination and their further growth in the package as seen in Table 4. Alçiçek (2011) emphasized that lactic acid bacteria (LAB) may be effective, especially in vacuum packaged products and they cause sour odors and flavors. After 3 month storage, significantly higher $(\mathrm{p}<0.05)$ levels of LAB were counted for all three groups compared to those of liquid smoked and cooked samples. Overall, similar levels of TVC, yeast and mold and LAB were found after the storage for groups S, WS and BS.

\section{Computer Based Image Analysis Results}

In seafood, flesh color is a very important sensory parameter in consumers' decisions. Similarly, it is also crucial for smoked food products. The main problem with the color of smoked fish is non-homogenous color distribution as a result of raw material quality and traditional smoking process. On the other hand, liquid smoke condensates gave an important chance to producers by the homogenized color of the smoked fillets.

$L^{*}$ value gives information about the brightness of the products. The $L^{*}$ value of the products after salting decreased significantly compared to the initial $L^{*}$ value $(\mathrm{P}<0.05)$. The reason for this decrease in $L *$ is most likely a modification of the myofibrils during salting and the removal of the blood in the muscle. After smoking and cooking processes, an extraordinary decrease in $L^{*}$ levels were observed $(\mathrm{P}<0.05)$ in all three groups, with group $\mathrm{S}$ and BS samples having significantly darker colour (23.63 and 25.69, respectively) than that of group WS samples (38.60). These results were compatible with Kong et al. (2015). According to Vidal et al. (2016), there are three reasons of this change; the first is the effect of colorant compounds of smoke condensate on fillet surface, second is the interaction between meat and the condensate components and third is to combine effects of both facts. During the 3 month storage, lightness values were randomly changed among the groups. $L^{*}$ value significantly increased for group $S$, decreased for group WS and did not change significantly $(\mathrm{P}>0.05)$ for group BS.

Slight but statistically important reductions were also observed for $a^{*}$ value due to salting $(\mathrm{P}<0.05) . a^{*}$ value is expected to be high in smoked products. However, it is undesirable to be too high. After liquid smoking and cooking, $a^{*}$ value remarkably increased for all three groups. However, the redness of the samples decreased during the storage for all the groups giving significantly lower level of $a^{*}$ for group BS samples than those of group $\mathrm{S}$ and WS. The main reasons could be the low initial $a^{*}$ value of BS and yellow-brownish color that the application of brown sugar gave to the product.

$b^{*}$ value did not show meaningful changes after any of the treatments. This is probably due to the fact that the main reason $b *$ is not dominantly influenced by the 
salting and smoking processes. However, the S and WS groups showed fluctuations, while the BS group decreased steadily during the storage. This is due to the yellow-brown colour that the "molasses" substance contained in the brown sugar gives to the product.

\section{Sensory Analysis Results}

The liquid smoke application is known to add a unique smell, colour, and aroma to the products. This is the characteristics distinguished and emphasized by consumers who consume smoked products. In this study, panellists did sensory analysis on the trout samples after liquid smoking and cooking as well as after 3 month storage. For all parameters, a dramatic decrease $(\mathrm{P}<0.05)$ was seen in all three groups as a result of storage.

For colour, no significant difference was found between the groups. At the end of three month storage, the panellists evaluated BS colour as the best colour group. BS (2.80) and group S (2.67) samples had significantly $(\mathrm{P}<0.05)$ better color attributes than that of group WS (2.53). As for the overall appearance, group $S$ samples (4.13) was significantly worse than those of groups WS (4.53) and BS (4.40). At the end of the storage group WS had better appearance. After the storage, group WS was rated as the best in term of their taste followed by group S. Group WS samples were also selected as superior among the groups in terms of odor and texture as well. Overall, group WS and BS were superior for the sensory properties following the liquid smoking and cooking treatments. However, group BS seemed to be the best group based on sensory evaluations by the panellists at the end of the storage period.

\section{Conclusion}

In this study, the effect of using salt only or salt-white sugar or salt-brown sugar mixtures on some physicochemical, microbiological and sensory parameters of rainbow trouts after salting, liquid smoking and cooking as well as 3 month storage at $4^{\circ} \mathrm{C}$ were investigated. Overall, not a striking alteration was monitored as a result of using different salt mixtures based on the results except for sensory analysis. According to sensory results, trout samples salted using salt and white sugar mixture (50$50 \%$ ) were better appreciated by the panellists in terms of their superior appearance, taste, odor and texture indicating that the smoked trout samples salted with this mixture could be more consumer-favoured product in comparison with the salt only or salt brown-sugar mixture used liquid smoked trout.

\section{Acknowledgements:}

This work was supported by Çanakkale Onsekiz Mart University Scientific Research Coordination Unit. Project number FBE-2014-433.

\section{References}

Alçiçek Z. 2011. Determination shelf life and pahs content of smoked anchovy (Engraulis encrasicolus, linneaus, 1758) nugget with different level liquid smoke flavors during chilled storage. J Anim Vet Adv. doi: 10.3923/javaa.2011.2691.2695
Alçiçek Z. 2011. The effects of thyme (Thymus vulgaris L.) oil concentration on liquid-smoked vacuum-packed rainbow trout (Oncorhynchus mykiss Walbaum, 1792) fillets during chilled storage. Food Chem 128:683-688. doi: 10.1016/j.foodchem.2011.03.087

Alcicek Z, Atar HH. 2010. The effects of salting on chemical quality of vacuum packed liquid smoked and traditional smoked rainbow trout (Oncorhyncus mykiss) fillets during chilled storage. J Anim Vet Adv. doi: 10.3923/javaa.2010.2778.2783

Alçiçek Z, Zencir Ö, Çelik Çakiroğullari G, Atar HH. 2010. The Effect of Liquid Smoking of Anchovy ( Engraulis encrasicolus , L. 1758) Fillets on Sensory, Meat Yield, Polycyclic Aromatic Hydrocarbon (PAH) Content, and Chemical Changes. J Aquat Food Prod Technol 19:264-273. doi: 10.1080/10498850.2010.512995

Anonymous. 2000. Tarım ve Köy İşleri Bakanlığı Koruma ve Kontrol Genel Müdürlüğü Su Ürünleri Kalite Kontrol El Kitabı, Ankara.

Arvanitoyannis IS, Kotsanopoulos KV. 2012. Smoking of Fish and Seafood: History, Methods and Effects on Physical, Nutritional and Microbiological Properties. Food Bioprocess Technol 5:831-853. doi: 10.1007/s11947-011-0690-8

Ayvaz Z, Balaban MO, Kong KJW. 2017. Effects of Different Brining Methods on Some Physical Properties of Liquid Smoked King Salmon. J Food Process Preserv 41:e12791. doi: 10.1111/jfpp.12791

Baumgartner A, Murphy M, Daly C, Fitzgerald GF. 1986. Conjugative co-transfer of lactose and bacteriophage resistance plasmids from \&lt;em\&gt;Streptococcus cremoris\&lt;/em\&gt; UC653. FEMS Microbiol Lett 35:233 LP-237.

Bligh EG, Dyer WJ. 1959. A rapid method of total lipid extraction and purification. Can J Biochem Physiol 37:911-917.

Esaiassen M, Østli J, Joensen S, et al. 2005. Brining of cod fillets: effects of phosphate, salt, glucose, ascorbate and starch on yield, sensory quality and consumers liking. LWT - Food Sci Technol 38:641-649. doi: 10.1016/j.lwt.2004.08.011

Espe M, Nortvedt R, Lie Ø, Hafsteinsson H. 2002. Atlantic salmon (Salmo salar, L) as raw material for the smoking industry. II: Effect of different smoking methods on losses of nutrients and on the oxidation of lipids. Food Chem 77:41-46. doi: 10.1016/S0308-8146(01)00320-X

FAO. 2016. FAO Statistical Query result. http://www.fao.org/figis/servlet/SQServlet?file=/work/FIGIS/pr od/webapps/figis/temp/hqp_3443443714964013424.xml\&outty pe $=$ html. Accessed 15 Nov 2016

Goulas AE, Kontominas MG. 2005. Effect of salting and smokingmethod on the keeping quality of chub mackerel (Scomber japonicus): Biochemical and sensory attributes. Food Chem 93:511-520. doi: 10.1016/j.foodchem.2004.09.040

Gürlekoğlu G. 2011. The Effects of Different Wood Sawdusts on Color and Sensory Properties of Hot Smoked Rainbow Trout (Oncorhynchus mykiss). Cukurova University

Hong H, Luo Y, Zhou Z, Shen H (2012) Effects of low concentration of salt and sucrose on the quality of bighead carp (Aristichthys nobilis) fillets stored at 4 ??c. Food Chem 133:102-107. doi: 10.1016/j.foodchem.2012.01.002

Hyldig G. 2010. Sensory aspects of heat-treated seafood. (Ed: Leo M.L. Nollet, Fidel Toldra) in Handbook of Seafood and Seafood Products Analysis, 499-512, CRC Press, ISBN 9781420046335

King AD, Hocking AD, Pitt JI. 1979. Dichloran-rose bengal medium for enumeration and isolation of molds from foods. Appl Environ Microbiol 37:959-964.

Kolsarici N, Özkaya Ö. 1998. Gökkuşağı Alabalığı ( Salmo gairdneri )'nın Raf Ömrü Üzerine Tütsüleme Yöntemleri ve Depolama Sıcaklığının Etkisi 1. 22:273-284.

Kong KJW, Alçiçek Z, Balaban MO. 2015. Effects of dry brining, liquid smoking and high-pressure treatment on the physical properties of aquacultured King salmon ( Oncorhynchus tshawytscha ) during refrigerated storage. J Sci Food Agric 95:708-714. doi: 10.1002/jsfa.6754

Leroi F, Joffraud JJ. 2000. Salt and Smoke Simultaneously Affect Chemical and Sensory Quality of Cold-Smoked Salmon during $5^{\circ} \mathrm{C}$ Storage Predicted Using Factorial Design. J Food Prot 63:1222-1227. 
Lingbeck JM, Cordero P, O’Bryan CA, et al. 2014. Functionality of liquid smoke as an all-natural antimicrobial in food preservation. Meat Sci 97:197-206. doi 10.1016/j.meatsci.2014.02.003

Martinez O, Salmerón J, Guillén MD, et al. 2012. Physicochemical, sensorial and textural characteristics of liquid-smoked salmon (Salmo salar) as affected by salting treatment and sugar addition. Int J Food Sci Technol 47:1086-1096. doi: 10.1111/j.1365-2621.2012.02945.x

Martinez O, Salmerón J, Guillén MD, Casas C. 2011. Characteristics of dry- and brine-salted salmon later treated with liquid smoke flavouring. Agric Food Sci 20:217-227. doi: $10.2137 / 145960611797471543$

Oehlenschlager J. 2014. Seafood Quality Assessment. Seaf Process Technol Qual Saf 361-386. doi: 10.1002/9781118346174.ch14

Sahoo J, Sajala K, Kumar M. 2004. Low-salt meat products as health food. Nat Prod Radiance 3:309-317.
Šimko P. 2002. Determination of polycyclic aromatic hydrocarbons in smoked meat products and smoke flavouring food additives. J Chromatogr B 770:3-18. doi: 10.1016/S0378-4347(01)00438-8

Turkish Food Composition Database, 2014 URL: http://www.turkomp.gov.tr/?locale=en

Varlet V, Serot T, Prost C. 2010. Smoke Flavoring Technology in Seafood. Handb Seaf Seaf Prod Anal 233-254.

Vidal NP, Goicoechea E, Manzanos MJ, Guillén MD. 2016. Effect of Smoking Using Smoke Flavorings on Several Characteristics of Farmed Sea Bass ( Dicentrarchus labrax ) Fillets and on their Evolution During Vacuum-Packed Storage at Refrigeration Temperature. J Food Process Preserv 0:1-15. doi: $10.1111 /$ jfpp. 12800

Yagiz Y, Balaban MO, Kristinsson HG, et al. 2009. Comparison of Minolta colorimeter and machine vision system in measuring colour of irradiated Atlantic salmon. J Sci Food Agric 89:728730. doi: $10.1002 /$ jsfa. 3467 